\title{
Assessing age distributions of killer whale Orcinus orca populations from the composition of endogenous fatty acids in their outer blubber layers
}

\author{
David P. Herman ${ }^{1, *}$, Craig O. Matkin ${ }^{2}$, Gina M.Ylitalo ${ }^{1}$, John W. Durban ${ }^{3,5}$, \\ M. Bradley Hanson ${ }^{1}$, Marilyn E. Dahlheim ${ }^{3}$, Janice M. Straley ${ }^{4}$, Paul R. Wade ${ }^{3}$, \\ Karen L. Tilbury ${ }^{1}$, Richard H. Boyer ${ }^{1}$, Ronald W. Pearce ${ }^{1}$, Margaret M. Krahn ${ }^{1}$ \\ ${ }^{1}$ NOAA Fisheries, Northwest Fisheries Science Center, 2725 Montlake Boulevard East, Seattle, Washington 98112, USA \\ ${ }^{2}$ North Gulf Oceanic Society, PO Box 15244, Homer, Alaska 99603, USA \\ ${ }^{3}$ NOAA Fisheries, Alaska Fisheries Science Center, 7600 Sand Point Way NE, Seattle, Washington 98115, USA \\ ${ }^{4}$ University of Alaska Southeast, 1332 Seward Avenue, Sitka, Alaska 99835, USA \\ ${ }^{5}$ Center for Whale Research, 355 Smugglers Cove Road, Friday Harbor, Washington 98250, USA
}

\begin{abstract}
Knowledge of the age distributions of killer whale Orcinus orca populations is critical to assess their status and long-term viability. Except for accessible, well-studied populations for which historical sighting data have been collected, currently there is no reliable benign method to determine the specific age of live animals for remote populations. To fill this gap in our knowledge of age structure, we describe new methods by which age can be deduced from measurements of specific lipids, endogenous fatty acids (FAs) and FA ratios present in their outer blubber layers. Whereas correlation of wax and sterol esters with age was reasonable for female 'resident' killer whales, it was less well-defined for males and 'transients.' Individual short-, branched-, and odd-chain FAs correlated better with age for transients and residents of both sexes, but these single parameter relationships were population specific and seemingly varied with long-term diet. Alternatively, a simple, empirical multi-linear model derived from the combination of 2 specific FA ratios enabled the ages of individual eastern North Pacific killer whales to be predicted with good precision $(\sigma= \pm 3.8 \mathrm{yr}$ ), appeared to be independent of individual diet and was applicable to both genders and ecotypes. The model was applied to several less well-studied killer whale populations to predict their age distributions from their blubber FA compositions, and these distributions were compared with a population of known age structure. Most interestingly, these results provide evidence for the first time that adult male transient killer whales appear to have lower life expectancies than do their resident counterparts in Alaska.
\end{abstract}

KEY WORDS: Killer whale $\cdot$ Orcinus orca $\cdot$ Ageing $\cdot$ Biopsy sampling $\cdot$ Fatty acids $\cdot$ Northeast Pacific

\section{INTRODUCTION}

Detailed information on age structure is essential for understanding population dynamics, as key demographic characteristics such as survival, fecundity and dispersal probabilities typically vary with individual age (Caughley 1966, Caswell 2001, Matkin et al. 2003, Olesiuk et al. 2005). Variations in these vital rates and the resultant levels of abundance are critical factors that dictate population growth and ultimately population viability (Akcakaya 2000). As a result, population status is most appropriately assessed from agestructured models that require knowledge of the age of each individual, and demographic rates are then assessed for distinct age classes (Brault \& Caswell 1993, Caswell 2001). For example, Brault \& Caswell (1993) 
describe a study - a stage-classified matrix population model - to predict pod-specific growth rates of 18 subpopulations of eastern North Pacific southern and northern resident killer whales. In their study they identified juvenile and adult survival as the most important factor governing population growth with fecundity being somewhat less important. They also tested the hypothesis that the age structure of these resident killer whale populations, in turn, influences their vital rates, and hence, also the fitness and health of the individual members.

Age assessment of free-ranging cetaceans can be problematic as it requires the capture and restraint of individuals to allow removal of a tooth for ageing (e.g. Read et al. 1993). Capture operations have primarily been restricted to smaller cetacean species and are not feasible for larger species such as killer whales. Age distribution data are sometimes available for species acquired in directed fisheries (Kasuya \& Marsh 1984), strandings (Stolen \& Barlow 2003) or incidentally caught as fisheries by-catch (Read \& Hohn 1995), but the utility of such samples is generally constrained by biases resulting from age selectivity. For example, Lockyer et al. (2001) reported that by-catch of dolphins and porpoise were often biased towards young animals whereas adult porpoise predominated in stranded samples. Another complication is that in many cases stranded animals will be a mixture of animals that died as a result of fisheries operations and from natural causes. Moreover, for killer whales in particular, sample sizes of stranded or bycaught animals are usually quite small, resulting in poorly defined age distributions.

Alternatively, long-term photo-identification studies have been possible for a limited number of killer whale Orcinus orca populations occurring within protected, coastal areas. Research studies of this nature provide longitudinal life history data on individuals that have been repeatedly documented over time (Olesiuk et al. 1990, 2005, Matkin 2003). However, such long-term studies are difficult to maintain, particularly for species inhabiting inaccessible offshore environments. These long-term studies have provided baseline data equating known ages of killer whales to observable physical characteristics (e.g. Olesiuk et al. 1990, Durban \& Parsons 2006). This has enabled assumptions about age to be made for remote killer whale populations that have not been amenable to long-term recurrent study, with ages of individual whales being estimated from characteristics such as height and width of the dorsal fin (Matkin et al. 2003). For males, these methods of age estimation generally require some additional assumptions regarding the median age at which males become physically mature ( 21 yr), which is combined with observational data noting the years in which the dorsal fin begins to grow or is fully developed (Bigg et al. 1990, Olesiuk et al. 1990, Matkin et al. 2003). For females, assumptions regarding the age of maturity ( 15 yr) are determined from the year juvenile-sized females give birth to their first calf, or in the case of adult females, from back-calculations based on the date of birth of their oldest known offspring. Ageing killer whales using these methods have varying degrees of uncertainty associated with their values dependent upon the sex and age class of each whale as well as the time frames in which observational data collection began. These allometric-based methods are most accurate for non-adult animals (calves, juveniles and sub-adults) that are continuously growing in physical size and much less accurate for adult-aged whales.

Here we introduce an alternative approach to estimating ages of free-ranging killer whales, based on the fatty acid compositions of their outer blubber layers. Outer blubber biopsy samples can be collected remotely using lightweight darts that elicit only minor behavioral reactions (Barrett-Lennard et al. 1996) without the need for restraint. Starting in the 1990s, several studies have used skin and blubber biopsy samples to study the population biology of killer whales in the eastern and northern North Pacific Ocean. Three distinct killer whale ecotypes, denoted as 'residents,' 'transients' and 'offshores' have been identified in this region (e.g. Ford et al. 2000), and molecular genetic analyses of biopsy samples has demonstrated fixed differences in their genetics (Hoelzel et al. 1998, 2002, Barrett-Lennard 2000). Analyses of biopsy samples for stable isotope ratios, fatty acid compositions and organochlorine contaminant burdens have been used to corroborate observations about prey differences, with resident and offshore populations feeding on fish, and transients feeding on marine mammals (Herman et al. 2005, Krahn et al. 2007a). These chemical signals have also been used to document differences in contaminant burdens and ratios, infer life history correlations within populations and reveal differences in foraging habitat between populations (Ross et al. 2000, Ylitalo et al. 2001, Krahn et al. $2004,2007 a$ ). In this study we extend the use of these samples to describe a viable, non-lethal method for ageing remote killer whale populations from measurements of specific fatty acids present in their blubber. Specifically, the outer blubber fatty acid compositions of numerous known-age killer whales in the eastern North Pacific Ocean have been measured and these data used to derive an empirical age-fatty acid model, which in turn should enable the ages of unknownaged whales to be determined with good precision. Such an approach has previously been demonstrated for other marine mammal species wherein very shortchain fatty acids (e.g. isovaleric acid) present in the outer thorax blubber tissues of several cetacean spe- 
cies increase with body length, and in the specific case of adult male harbor porpoises, generally increase with known age (Koopman et al. 1996, 2003). Because the killer whale age-fatty acid relationships described herein are entirely empirical in nature, the underlying biochemical mechanisms responsible for the apparent relationships between specific fatty acids (or fatty acid ratios) with known age are unknown at present and are beyond the scope of the current study.

\section{MATERIALS AND METHODS}

Killer whales sampled. During the months May through September from 1994 to 1999 blubber biopsy samples were collected from resident and transient killer whales of known age from the Kenai Fjords/ Prince William Sound region of Alaska, USA, as part of an examination of environmental contaminant levels (Ylitalo et al. 2001). In this study the proportions of wax and sterol esters measured in the blubber of these whales from 1994 to 1999 (see Table A1 in the Supplementary Material available at: www.int-res.com/ articles/suppl/m372p289_app.pdf; Ylitalo et al. 2001) were combined with wax and sterol ester results obtained for killer whale biopsy samples acquired between 2001 and 2006 to determine the extent wax and sterol esters correlate with killer whale age. Age was based on long-term sighting histories (Matkin et al. 1999).

In the spring and summer months of 2001 to 2005, killer whale skin and blubber biopsy samples $(n=138)$ were collected in Alaska (southeast Alaska, SEAK; Gulf of Alaska, GOA; eastern Aleutian Islands, EAI; and the central Aleutian Islands, CAI) and from the Washington coast $(n=2)$ from live, presumably healthy offshore, resident and transient whales. These biopsy samples were analyzed for fatty acids (FAs), stable isotopes, lipid classes and persistent organic pollutants (POPs) as part of a killer whale feeding ecology study and reported in Herman et al. (2005) and Krahn et al. (2007a); full demographic information for each individual killer whale as well as details of the sampling locations and protocols is provided in these publications.

In the summer of 2003, 2 west coast transient killer whales (animal identification nos. T-93 and T-85; Table A1) and 3 resident killer whales (AF19, AF30, AF47; Table A1) of known ages were sampled as part of a NOAA Steller Sea Lion Research Initiative grant and also used in this study to establish the relationship between killer whale age and outer blubber FA composition. Ages of these whales were known from longterm photo-identification data reported in published catalogues, specifically Matkin et al. (1999) and Ford \& Ellis (1999).
In February 2005, 3 known-age transient killer whales (T71a, T71b and T124a; Table A1) from the west coast transient population entered Hood Canal, Washington, and were biopsy sampled as part of a continuation of a North Pacific Research Board feeding ecology study (Project No. 0535). Ages for these whales were determined from long-term photo-identification monitoring (Ford \& Ellis 1999, G. M. Ellis unpubl. data). Later in the spring and summer of 2005, blubber biopsy samples from an additional 26 resident and transient killer whales were collected in Alaska (including the Bering Sea) and analyzed for FAs, stable isotopes, lipid classes and POPs as part of the same feeding ecology project. Of these additional 26 Alaskan killer whales sampled in spring/summer of 2005, only 7 younger whales could be positively assigned known ages because of relatively short sighting histories in this area (see Table A1).

Finally, in May and June 2006, 6 whales from the west coast southern resident population of known age were biopsied in the US territorial waters of northern Puget Sound, Washington, as part of a study to assess POP burdens, paternity and feeding ecology (Krahn et al. 2007b). Ages for these whales were known from long-term photo-identification records and from unpublished data collected by the Center for Whale Research, Washington (Ford et al. 2000, J. K. B. Ford, G. M. Ellis and K. C. Balcomb unpubl. data). FA data from these 6 biopsy samples were combined with FA results obtained from the outer blubber layers of 2 additional southern resident killer whales (L60 and L98; Table A1); one died from an unknown cause in April 2002 and the other as the result of injuries incurred during an accidental encounter with a boat propeller in March 2006. Necropsy samples from the outermost blubber layers ( 0 to $2 \mathrm{~cm}$ ) were acquired from these 2 whales, and lipids were extracted and analyzed for fatty acids using the same method used for all biopsy blubber samples analyzed as part of this study. A map depicting the general areas within the eastern North Pacific Ocean from which all of the blubber samples were collected, as well as the specific locations of the known age killer whales described in detail for this study, is shown in Fig. 1.

The FA and lipid class results obtained from analyses of all of the blubber samples were used to: (1) establish the relationship of killer whale age with lipid class (in particular wax and sterol esters), individual FAs, and FA ratios, and (2) estimate the age distributions of various killer whale populations inhabiting the eastern North Pacific Ocean (ENP). Among all these killer whale biopsy samples, only a small subset $(n=59)$ was collected from animals of known age. It is the FA results from these 59 killer whale (KW) samples that form the basis set from which the KW(age)-FA model described here was derived. The sex, collection dates, 


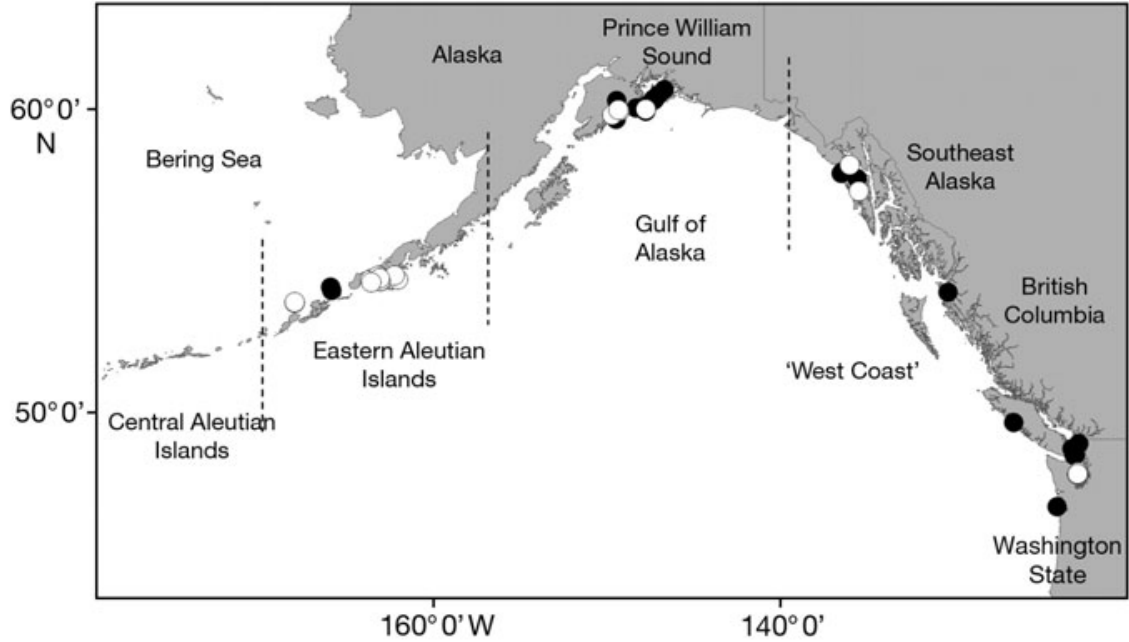

Fig. 1. Orcinus orca. Sampling locations of the 59 eastern North Pacific knownage (๑) resident and (O) transient killer whales analyzed as part of this study

age classes and collection locations of these knownage whales are provided in Table A1. The individual ages of all unknown-age killer whales (as well as age distributions of various killer whale populations) were then predicted from this model.

Known sampling biases. Unfortunately, during sampling operations conducted in support of these studies, no attempt was made to randomly sample individual whales within (or among) all age classes (i.e. calves, juveniles, subadults and adults). Instead, sampling was biased toward larger adult whales with a tendency to avoid sampling the smaller, fast-moving juveniles, calves, or reproductive-age females accompanied by small calves. Consequently, among all the killer whale biopsy samples collected and analyzed to date, only the adult-age ( $\geq 20 \mathrm{yr}$ ) males are deemed to have been sampled randomly and will, therefore, be representative of the age distributions of the entire population of adult males. All other age classes of males, and all age classes of females, will be under-represented as a result of this known sampling bias. Thus, all comparisons between age distributions derived from blubber FA results for the numerous regional populations of killer whales described in this study will necessarily be restricted to adult-age males.

Sample preservation and integrity. All biopsy samples were stored frozen at $-80^{\circ} \mathrm{C}$ until analyzed. In an attempt to standardize sample size, frozen biopsy samples were subjected to 2 lateral cuts. First, the epidermis was removed by cutting the sample 1 to $2 \mathrm{~mm}$ from the inside edge of the epidermis and then a second lateral cut was made $2 \mathrm{~cm}$ from the inside edge of the epidermis (sample length $\sim 1.8 \mathrm{~cm}$ ). Samples containing less than $5 \%$ total lipid are assumed to be non- representative as the result of excessive lipid loss during biopsy dart recovery efforts in the field or represent blubber at depths substantially less than $2 \mathrm{~cm}$ owing to oblique, non-normal penetration of the biopsy dart during sampling operations (Krahn et al. 2004). Thus, consistent with our previous studies of killer whale biopsy samples (Ylitalo et al. 2001, Krahn et al. 2004, Herman et al. 2005), blubber biopsy samples having $<5 \%$ total lipid (wet weight basis) in their outer blubber layers were excluded from all models and data summary results.

Fatty acid and lipid class analyses. Blubber FAs ranging in carbon chain length from $\mathrm{C} 10$ to $\mathrm{C} 24$ were measured using a previously reported analytical method (Krahn et al. 2004, Herman et al. 2005), and their weight percent compositions (wt\%) were expressed in units of fatty acid methyl esters (FAMEs). Unfortunately, analysis of very short-chain length FAs (i.e. C5 to C9) cannot be measured by this analytical method. Thus, blubber composition results for very short-chain length FAs could not be similarly tested to determine whether any correlate sufficiently well with killer whale age so as to be quantitatively useful. For the purpose of this manuscript, we define very short-chain, short-chain and long-chain FAs to have carbon lengths of C5 to C9, $\mathrm{C} 10$ to $\mathrm{C} 17$ and $\mathrm{C} 18$ to $\mathrm{C} 24$, respectively. The n-number standard nomenclature system was used for abbreviating the names of these FAs, where the number following the ' $n$ ' symbol appearing in the abbreviation refers to the carbon position of the first double bond relative to the alkyl end of the molecule. A full list of all 83 FAs measured as part of this study (of which 3 were added as internal standards), their abbreviations, systematic and trivial names, as well as identification of the subsets of FAMEs that were positively and tentatively identified, and quality assurance procedures can be found in Sloan et al. (2006).

Blubber samples of killer whales were analyzed for percent lipid classes (relative to sample wet weights) using a thin-layer chromatography/flame ionization detection (TLC/FID) method (Ylitalo et al. 2005). Six lipid classes (i.e. wax esters, sterol esters, triglycerides, free fatty acids, sterols and phospholipids) were analyzed on Chromarod type S-III silica rods using a 60:10:0.02 hexane:diethyl ether:formic acid (v/v/v) solvent system and measured with a Iatroscan MK-6s (Shell-USA). In this system, wax esters co-elute with sterol esters. Therefore, wax and sterol esters are reported as a sum (wax/sterol esters). Percent total 
lipids were calculated by adding the wet weight concentrations of the 5 separated lipid classes. The concentrations of wax/sterol esters are also reported as percent of total lipid.

Statistical analyses. Multivariate and univariate analyses were conducted on transformed (arcsine, logarithm and square root) and non-transformed concentration data using JMP Statistical Discovery Software (PC professional edition, v5.01). The wax/sterol ester concentrations data were expressed on a wt \% composition basis relative to total lipid and these univariate wt $\%$ composition values were correlated with killer whale age using simple, non-weighted, linear leastsquares. Unless otherwise stated, all univariate means comparisons ( $p$-values) were computed using the Student's $t$ comparison test at $\alpha=0.05$ significance levels. All FAME concentration data were also expressed on a weight percent (wt\%) composition basis by dividing the concentration of each individual FAME by the sum of all FAMEs measured in the sample. Multi-linear regressions of the transformed and non-transformed FAMEs-age data for the known age killer whales were performed using the mixed (forward and backward) step-wise search procedure. The aim of these statistical analyses was to find an empirical model equation (univariate or multivariate) that would best predict the age of free-ranging killer whales. The optimum model equation derived by this procedure was then used in this study to predict the ages of a large number of individual killer whales of unknown age from their outer blubber compositions. In turn, the predicted ages of these individual killer whales will be used to derive age distribution estimates for several killer whale populations within the eastern North Pacific Ocean.

\section{RESULTS}

\section{Correlation between killer whale age and wax/ sterol esters}

The percent total lipid values of the known-age killer whale blubber samples acquired from 1994 to 1999 and analyzed for their lipid classes (including wax/sterol esters) ranged from 5 to $59 \%$ (Ylitalo et al. 2001). These data were combined with the wax/sterol ester data obtained from known-age killer whale biopsy samples acquired between 2002 and 2006 (Table A1; present study) and then subjected to a simple least squares regression analysis and results presented in Fig. 2. Only 4 of the known-age killer whale biopsy samples collected from 2002 to 2006 had total lipid values less than $5 \%$ and were excluded from this analysis for the reasons outlined above. The blubber of all of these samples con- tained primarily wax/sterol esters and triglycerides ( $>85 \%$ of the total lipid). Mean \pm SE percent wax/sterol esters in the transient whales $(35.3 \pm 3.4, \mathrm{n}=32)$ were significantly higher $(p=0.047)$ than in the residents $(26.9 \pm 2.4, \mathrm{n}=67)$. Moreover, females contained higher mean percent wax/ sterol esters than did males for both transient whales (females: $39.2 \pm 4.6, \mathrm{n}=22$; males: $26.6 \pm 6.8, \mathrm{n}=10$ ) and for resident whales

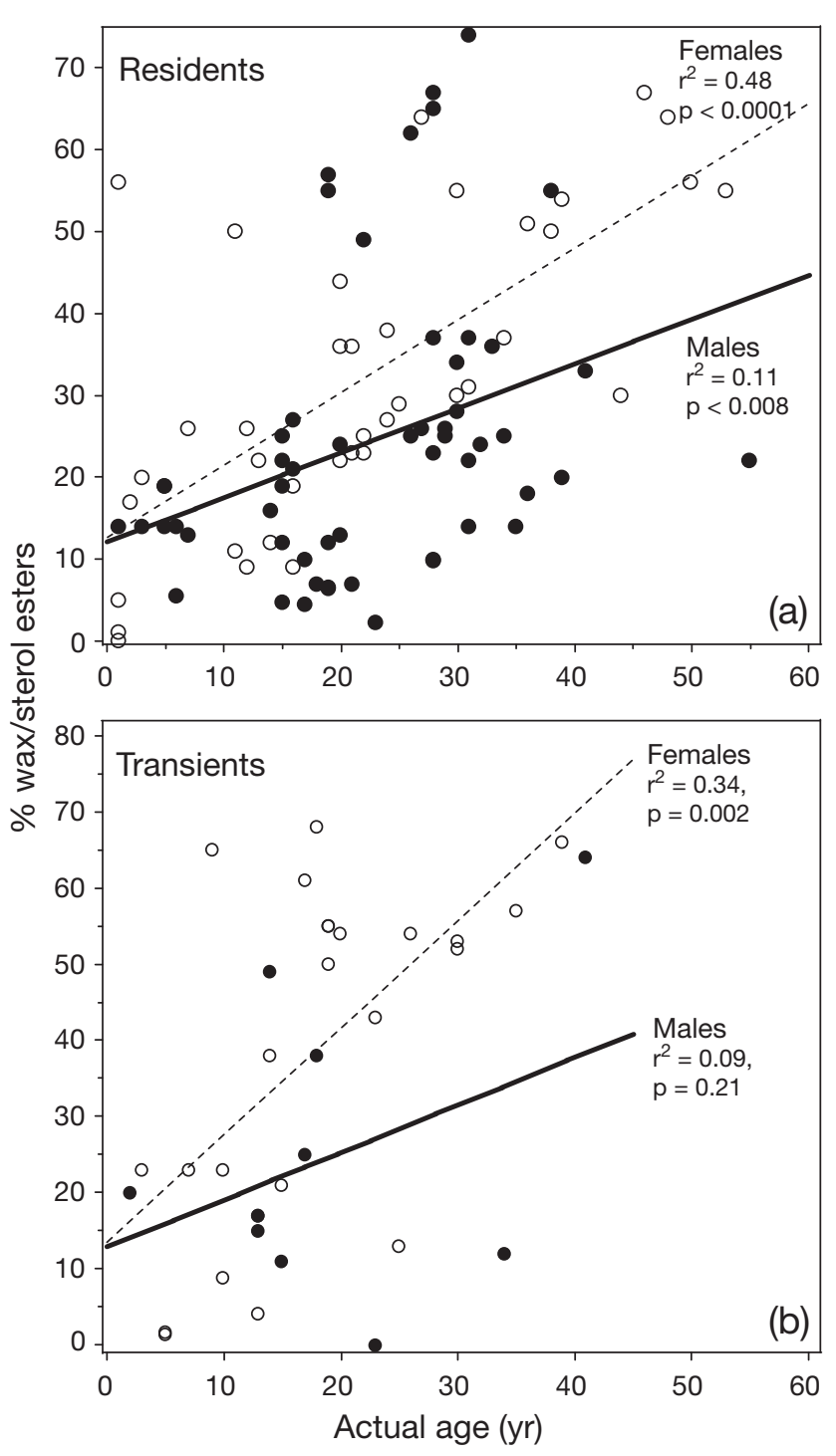

Fig. 2. Orcinus orca. Correlation of percent wax/sterol esters with age for eastern North Pacific (a) resident and (b) transient killer whales biopsy-sampled between 1994 and 2006 and described in Ylitalo et al. (2001), Herman et al. (2005), Krahn et al. (2007a), present study, Table A1 Supplementary Material available at: www.int-res.com/articles/suppl/m372 p289_app.pdf. (a) Female residents $(\mathrm{O}, \mathrm{n}=38)$, male residents $(\bullet, \mathrm{n}=52)$; (b) female transients $(\mathrm{O}, \mathrm{n}=21)$, male transients $(\bullet, n=10)$. The $\mathrm{p}$-values and correlation coefficients $\left(\mathrm{r}^{2}\right)$ obtained by linear least squares regression are imbedded within the figure 
(females: $34.3 \pm 3.6, \mathrm{n}=23$; males: $23.0 \pm$ $2.6, \mathrm{n}=44$ ) where the levels of statistical significance for this gender difference in wax/sterol ester composition for these 2 ecotypes were $\mathrm{p}=0.13$ and $\mathrm{p}=$ 0.014, respectively. Most interestingly, the proportion of wax/sterol esters in killer whale blubber generally increased with age for residents and transients of both genders (Fig. 2), but there was a very high degree of scatter among all these sub-populations $(0.09<$ $\left.r^{2}<0.48\right)$. Finally, wax/sterol ester concentrations of both ecotypes were observed to be better correlated with age for female killer whales than for males.

\section{Correlation between killer whale age and individual fatty acids}

Among the 80 individual FAs measured in the outer blubber of the eastern North Pacific killer whales, only 64 FAs were present at high enough concentrations in all samples to be accurately quantified. The abbreviated structures of these 64 quantifiable FAs are listed in Table 1. The killer whale biopsy samples listed in Table A1 were grouped by ecotype and the correlation (r) between killer whale age and FA composition for the resident $(\mathrm{n}=27)$ and transient $(\mathrm{n}=32$ ) populations represented were computed for each individual non-transformed FA. These values are reported in Table 1; p-values for FAs exhibiting statistically significant correlations with individual FAs are also indicated. In Table 1, the FAs are sorted from those having the highest (positive) correlation to those having the lowest (negative) correlation. With the exception of lauric acid (C12:0), the classes of FAs exhibiting the greatest correlations with killer whale age were observed to be the short-chain monounsaturated acids (most notably the $\Delta 5-, \Delta 7$ - and $\Delta 9$-dehydrogenase metabolites of $\mathrm{C} 12: 0, \mathrm{C} 14: 0$ and $\mathrm{C} 16: 0)$ and the shorter branched-chain FAs (most notably the iso- and anteiso-acids). Interestingly, saturated FAs of oddchain length exhibited a weaker, yet consistent, negative correlation with killer whale age for both ecotypes. The relationship between killer whale age and individual FAs for 6 representative FAs from among these 3 classes of FAs, in particular C16:1n9, C14:1n5, anteisoC15:0, iso-C16:0, C15:0 and C17:0, are depicted in
Table 1. Orcinus Orca. Linear correlation of individual fatty acids with age for resident and transient killer whales from the eastern North Pacific Ocean. Fatty acids are sorted from the highest (positive) to lowest (negative) mean correlation; asterisks indicate those that statistically increase (or decrease) with known age for both resident and transient populations at probabilitites: ${ }^{*} p<0.05$, ${ }^{* *} \mathrm{p}<0.01,{ }^{* * *} \mathrm{p}<0.001,{ }^{* * * *} \mathrm{p}<0.0001$

\begin{tabular}{|c|c|c|c|c|c|}
\hline \multirow{2}{*}{$\begin{array}{l}\text { Fatty acid } \\
\text { C12:0**** }\end{array}$} & \multicolumn{2}{|c|}{$\begin{array}{c}\text { Correlation coefficient }(\mathrm{r}) \\
\text { Residents } \\
(\mathrm{n}=27) \quad(\mathrm{n}=32)\end{array}$} & \multirow{2}{*}{$\begin{array}{l}\text { Fatty acid } \\
\text { iso-18 }\end{array}$} & \multicolumn{2}{|c|}{$\begin{array}{c}\text { Correlation coefficient }(\mathrm{r}) \\
\text { Residents } \\
(\mathrm{n}=27) \quad(\mathrm{n}=32)\end{array}$} \\
\hline & 0.85 & 0.84 & & -0.61 & -0.03 \\
\hline C16:1n9**** & 0.85 & 0.81 & C20:0 & -0.32 & -0.35 \\
\hline anteiso-C15:0**** & 0.79 & 0.83 & C17:0 & -0.20 & -0.48 \\
\hline $\mathrm{C} 14: 1 \mathrm{n} 9^{* * * *}$ & 0.87 & 0.70 & C18:2n6 & -0.16 & -0.52 \\
\hline $\mathrm{C} 14: 1 \mathrm{n} 7^{* * * *}$ & 0.84 & 0.73 & iso- 17 & -0.56 & -0.14 \\
\hline $\mathrm{C} 14: 1 \mathrm{n} 5^{* * * *}$ & 0.75 & 0.82 & C17:1ne & -0.09 & -0.61 \\
\hline $\mathrm{C} 12: 1^{* * * *}$ & 0.73 & 0.71 & $\mathrm{C} 16: 0$ & -0.50 & -0.23 \\
\hline iso-C14:0* & 0.46 & 0.79 & C18:3n3 & -0.24 & -0.52 \\
\hline $11 \mathrm{Me}-\mathrm{C} 14: 0^{* *}$ & 0.56 & 0.63 & C20:2n9 & -0.34 & -0.43 \\
\hline $2,6,10,14-\mathrm{C} 15: 0^{*}$ & 0.47 & 0.55 & $\mathrm{C} 16: 3 \mathrm{n} 4$ & -0.35 & -0.47 \\
\hline C11:0 & 0.35 & 0.57 & $\mathrm{C} 22: 6 \mathrm{n} 3$ & -0.38 & -0.49 \\
\hline $4,8,12-\mathrm{C} 13: 0$ & 0.39 & 0.50 & $\mathrm{C} 18: 1 \mathrm{n} 9^{*}$ & -0.42 & -0.45 \\
\hline C18:1n11* & 0.48 & 0.37 & C20:1n $5^{*}$ & -0.48 & -0.40 \\
\hline 7Me-C16:1 & 0.36 & 0.44 & C22:1n11 & -0.65 & -0.25 \\
\hline anteiso-C16:0 & 0.47 & 0.23 & $\mathrm{C} 20: 2 \mathrm{n} 6$ & -0.25 & -0.66 \\
\hline C10:0 & 0.19 & 0.35 & $\mathrm{C} 20: 1 \mathrm{n} 7$ & -0.41 & -0.53 \\
\hline C14:0 & -0.12 & 0.64 & $\mathrm{C} 16: 4 \mathrm{n} 1^{*}$ & -0.50 & -0.56 \\
\hline C16:1n7 & 0.47 & 0.02 & C18:2n7* & -0.51 & -0.63 \\
\hline C16:1n11 & -0.34 & 0.68 & $\mathrm{C} 20: 4 \mathrm{n} 6^{*}$ & -0.52 & -0.62 \\
\hline C24:1n9 & 0.12 & 0.19 & $\mathrm{C} 20: 5 \mathrm{n} 3^{* *}$ & -0.53 & -0.62 \\
\hline $\mathrm{C} 16: 1 \mathrm{n} 5$ & 0.25 & 0.01 & $\mathrm{C} 19: 0^{* *}$ & -0.58 & -0.58 \\
\hline anteiso-C17:0 & 0.04 & 0.16 & C18:0** & -0.56 & -0.62 \\
\hline $\mathrm{C} 20: 2 \mathrm{n} 11$ & 0.37 & -0.21 & $\mathrm{C} 22: 5 \mathrm{n} 3^{* *}$ & -0.58 & -0.61 \\
\hline C16:2n6 & 0.27 & -0.19 & C18:1n $7^{*}$ & -0.46 & -0.74 \\
\hline $\mathrm{C} 16: 4 \mathrm{n} 3^{*}$ & 0.46 & -0.38 & $\mathrm{C} 18: 3 \mathrm{n} 6^{* *}$ & -0.55 & -0.68 \\
\hline iso-C15:0* & -0.43 & 0.51 & $\mathrm{C} 20: 4 \mathrm{n} 3^{* *}$ & -0.56 & -0.67 \\
\hline $\mathrm{C} 16: 2 \mathrm{n} 4$ & 0.14 & -0.36 & $\mathrm{C} 20: 1 \mathrm{n} 9^{* *}$ & -0.63 & -0.64 \\
\hline C20:1n11 & -0.31 & 0.03 & $\mathrm{C} 18: 3 \mathrm{n} 4^{* *}$ & -0.58 & -0.73 \\
\hline iso-C16:0 & -0.70 & -0.28 & $\mathrm{C} 18: 4 \mathrm{n} 3^{* * *}$ & -0.67 & -0.65 \\
\hline C15:0 & -0.39 & -0.10 & $\mathrm{C} 20: 3 \mathrm{n} 6^{* *}$ & -0.62 & -0.71 \\
\hline $\mathrm{C} 18: 1 \mathrm{n} 13$ & -0.24 & -0.26 & $\mathrm{C} 18: 2 \mathrm{n} 4^{* * *}$ & -0.67 & -0.73 \\
\hline C22:1n9 & -0.14 & -0.40 & C18:1n $5^{* * *}$ & -0.74 & -0.67 \\
\hline
\end{tabular}

Fig. 3. Although there are reasonably well-defined correlations between killer whale age and FA composition for the 6 specific FAs depicted in Fig. 3, these relationships appear to be both ecotype specific and exhibit a rather high degree of scatter about their respective linear regression lines.

\section{Multi-linear killer whale age-fatty acid ratio model}

The blubber FA composition results (transformed and non-transformed) for the 59 known age killer whales listed in Table A1 were also subjected to multilinear regression analyses to determine whether multilinear combinations of individual FAs or multi-linear combinations of FA ratios could be found that would 

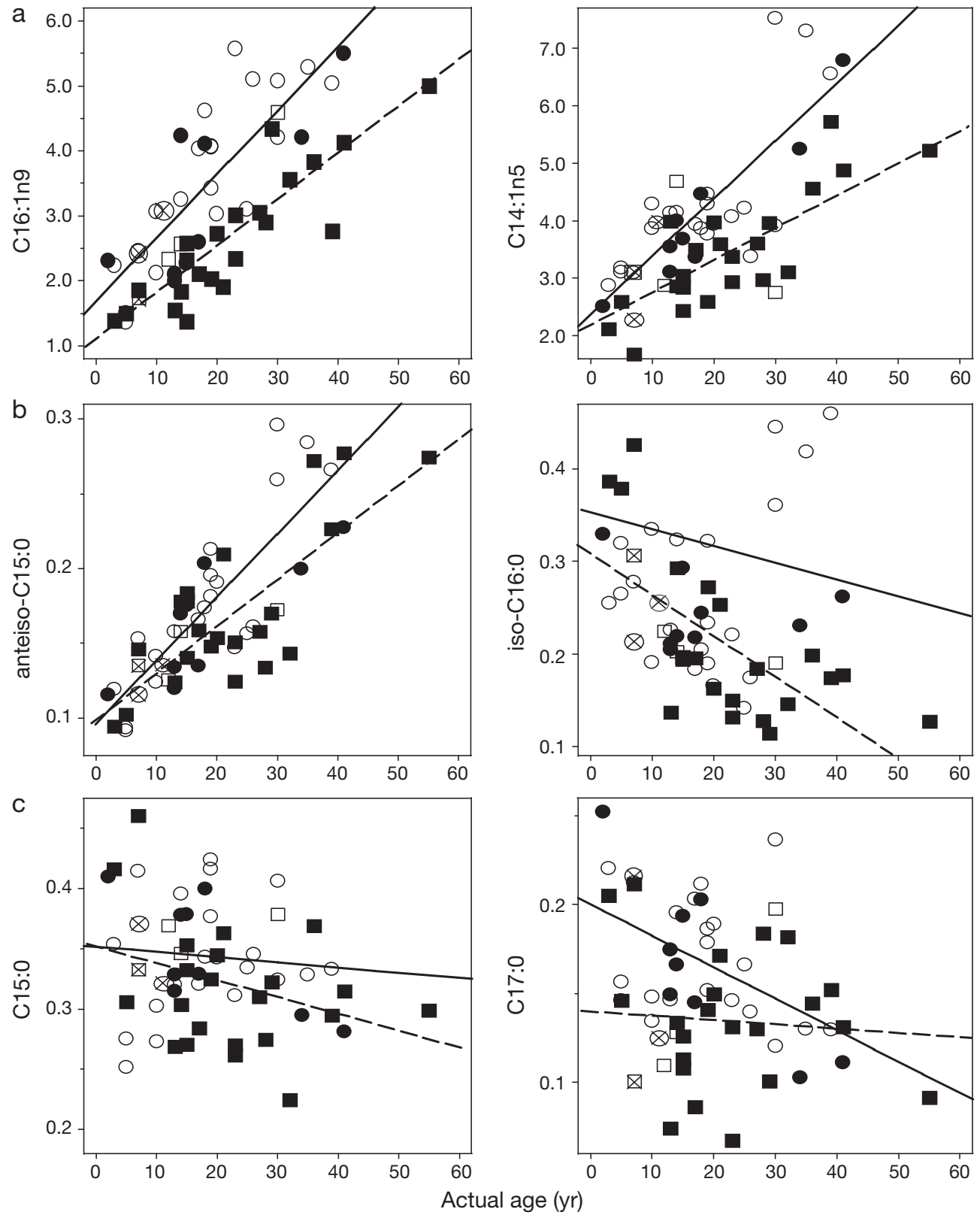

Fig. 3. Orcinus orca. Correlation of individual (a) short-chain monounsaturated-, (b) branched-, and (c) odd-chain fatty acids (wt\% composition) with known age (yr) for eastern North Pacific resident ( $\square$ and $\square$, dashed lines, $\mathrm{n}=27)$ and transient $(\mathrm{O}$ and $\bullet$, solid lines, $\mathrm{n}=32$ ) killer whales biopsy-sampled between 2002 and 2006 (see Table A1 in Supplementary Materials: www.int-res.com/articles/suppl/m372p289_app.pdf). Males $(\bullet$ and $\boldsymbol{\square}, \mathrm{n}=31)$, females $(\square$ and $\mathrm{O}, \mathrm{n}=25)$, unknown sex $(\otimes, \bigotimes$, $\mathrm{n}=3$ ). The $\mathrm{p}$-values for all regression lines were $<0.005$ except for iso-C16:0 transients and C17:0 residents, which were 0.13 and 0.73 , respectively. Correlation values (r) are found in Table 1

simultaneously reduce the variability (scatter) among individuals about the KW(age)-FA model equation and be largely independent of killer whale ecotype, gender, regional habitat and diet. Among the models tested, a simple linear combination of 2 pairs of nontransformed FA ratios was found to provide the best correlation between killer whale age and outer blubber FA composition for all killer whales independent of the demographics and presumptive diets. The optimum multi-linear equation using the mixed (forward and backward) step-wise search procedure was:

$$
\begin{array}{r}
\text { Age }(\mathrm{yr})_{\text {predicted }}=50.4 \times(\text { anteiso-C15:0/C15:0 }) \\
+0.561 \times(\mathrm{C} 16: 1 \mathrm{n} 9 / \text { iso-C16:0 })-14.5
\end{array}
$$

where the $p$-values associated with the parameter estimated (i.e. each of the 2 coefficients and the intercept 
of this equation) were all $<0.0001$ and had $\mathrm{SE}$ values of $3.52,0.071$ and 1.73 , respectively.

In Fig. 4, killer whale age predicted by Eq. (1) from the wt \% composition of anteiso-C15:0, C15:0, C16:1n9 and iso-C16:0 are shown plotted against known actual ages for each of the 59 killer whales listed in Table A1. Although some degree of scatter remains, the correlation between known and predicted age is very good $\left(\mathrm{r}^{2}=0.89, \mathrm{p}<0.0001\right)$. The KW(age)-FA model appears to be quite robust as evidenced by the fact that the data points are normally distributed about the multi-linear regression line (Fig. 4). Data normality is demonstrated in Fig. 5 where the distribution of the residuals about the multi-linear regression equation is shown plotted for the 59 known-age killer whale biopsy samples used to derive the model. The SD of this distribution of the residuals (age actual - age $\mathrm{e}_{\text {predicted }}$ ) is $3.82 \mathrm{yr}$.

\section{Age distribution of three ENP resident killer whale populations}

The KW(age)-FA model represented by Eq. (1) was then used to predict the ages of all killer whales for which outer blubber biopsy samples had been collected and analyzed in our laboratory for their fatty acid compositions. Among the numerous resident and transient killer whale populations studied to date in which blubber biopsy/necropsy samples were collected and analyzed for FAs (Herman et al. 2005, Krahn et al. 2007a), only 3 populations of killer whales had a sufficiently large number of males with known

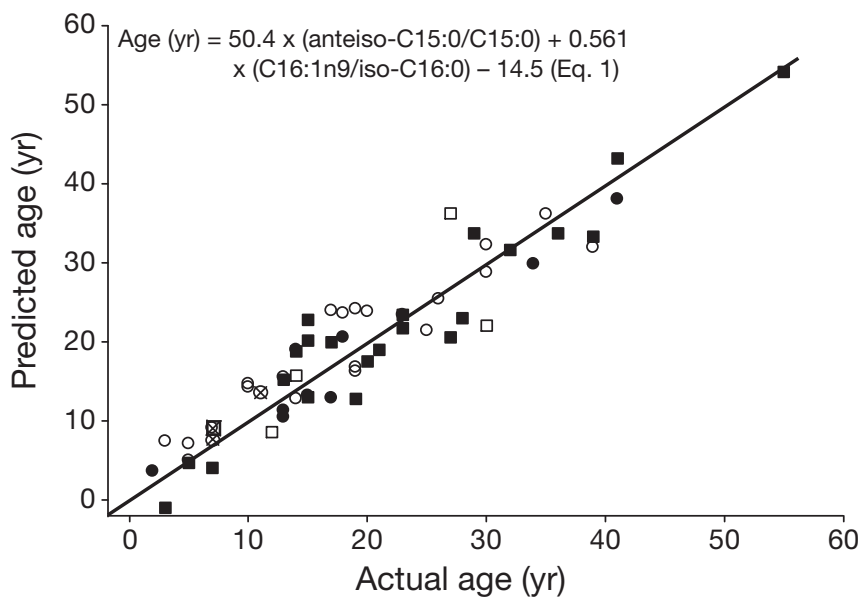

Fig. 4. Orcinus orca. Plot showing the multi-linear bivariate relationship ( $\mathrm{p}<0.0001, \mathrm{r}^{2}=0.89$ ) between the actual known ages of 59 resident and transient killer whales and the ages predicted from their outer blubber fatty acid compositions using the killer whale(age)-fatty acid model (Eq. 1). Solid line represents the point in the plot where predicted age $(\mathrm{yr})=$ actual age (yr). Transients ( 0 and $\mathrm{O}, \mathrm{n}=32$ ), residents $(\boldsymbol{\square}$ and $\square, \mathrm{n}=27$ ), males ( and $\boldsymbol{\square}, \mathrm{n}=31$ ), females ( $\bigcirc$ and $\square, \mathrm{n}=25$ ), unknown sex $(\otimes, \otimes, n=3)$

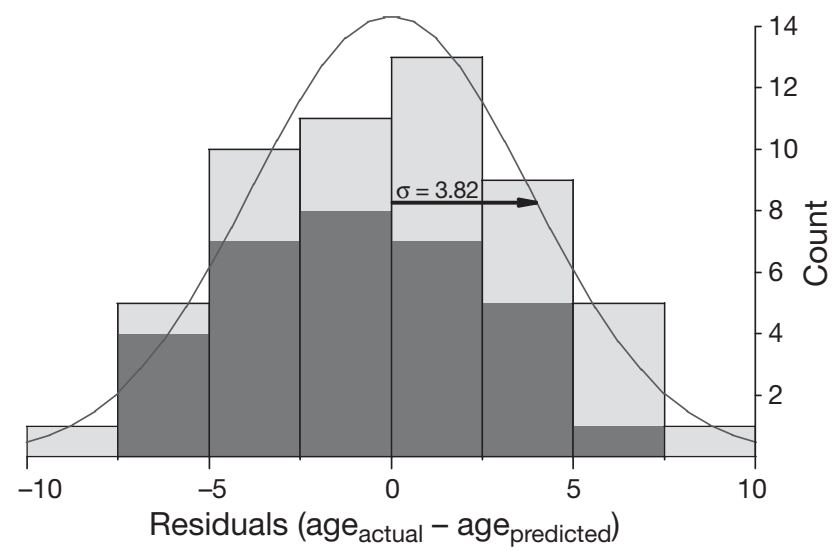

Fig. 5. Orcinus orcas. Histogram depicting the normal distribution of the residual differences between actual, known killer whale ages and their ages predicted from the killer whale (age)-fatty acid model (Eq. 1) for the individual killer whale biopsy samples shown plotted in Fig. 4. Transients (dark shading), residents (light shading). SD $(\sigma)$ of the distribution for both populations (transients and residents) was $3.82 \mathrm{yr}$

and/or predicted ages exceeding $20 \mathrm{yr}$ (EAI residents, $\mathrm{n}=19$; GOA residents, $\mathrm{n}=19$; EAI transients, $\mathrm{n}=13$ ). As stated above, only the males of adult age ( $>20 \mathrm{yr}$ ) are believed to have been sampled without discrimination (i.e. randomly) and it is, therefore, only this sex/age subgroup within the overall population from which it will be possible to estimate age distributions. In Fig. 6, the age distributions of all resident killer whales (males and females of all ages) biopsy sampled to date from the EAI $\left(\mathrm{n}_{\text {total }}=29\right)$ and GOA $\left(\mathrm{n}_{\text {total }}=28\right)$ and their ages predicted from Eq. (1) are presented. The median age of the adult males from these 2 regions are predicted to be 25.4 and $28.4 \mathrm{yr}$, respectively. For comparison, the age distribution of the entire population of west coast southern residents, $\mathrm{WC} / \mathrm{R}(\mathrm{SR})$, alive as of the spring of 2000 is also plotted in Fig. 6. The exact ages (birth years) for each of the $\mathrm{WC} / \mathrm{R}(\mathrm{SR})$ whales used to derive the age distribution plot depicted for this population were obtained from historical photographic records acquired over the last 35+ yr (Ford et al. 2000, Plater 2001, J. K. B. Ford, G. M. Ellis and K. C. Balcomb unpubl. data) and do not represent ages predicted by the KW(age)-FA model. The median age of the adult males $(n=7)$ for the entire southern resident population in the spring of 2000 was $24 \mathrm{yr}$ and was comparable with the mean ages of the 2 resident populations from Alaska.

\section{Comparison of age distributions for ENP transient and resident killer whale populations}

The ages of all individual resident and transient male killer whales biopsied in Alaska from 2001 to 

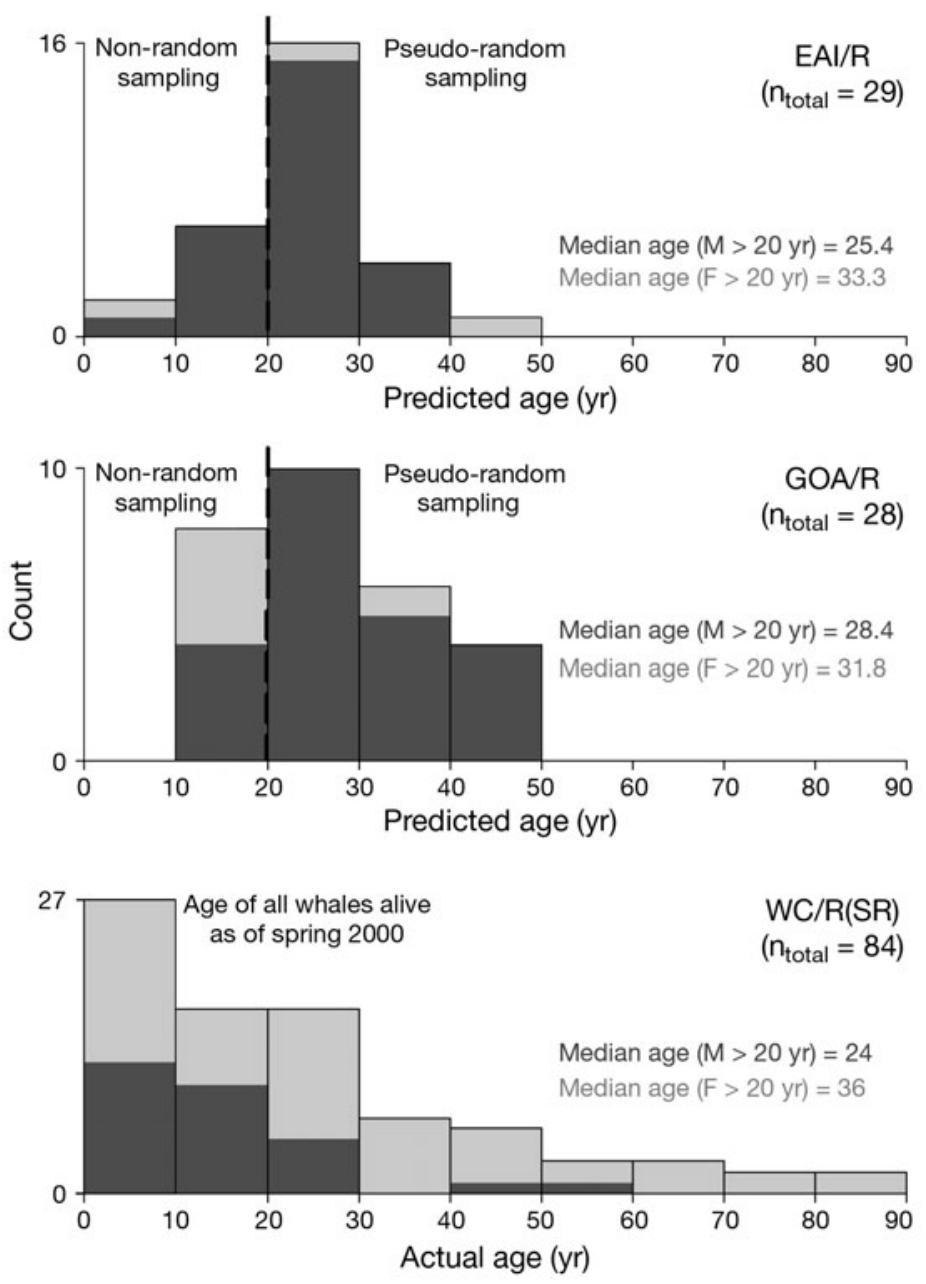

Fig. 6. Orcinus orca. Comparisons of the age distributions of 3 regional groups of eastern North Pacific resident killer whale populations. Ages of the individual eastern Aleutian Island resident (EAI/R) and the Gulf of Alaska resident (GOA/R) whales represented by these distributions were predicted using the killer whale (age)-fatty acid model (Eq. 1) from their measured outer blubber fatty acid compositions. In contrast, the age distribution of the west coast southern resident population, $\mathrm{WC} / \mathrm{R}(\mathrm{SR})$, was generated from the known age (birth year) data reported in Ford et al. (2000), Plater (2001) and J. K. B. Ford, G. M. Ellis and K. C. Balcomb (unpubl. data). Median ages for adult-age killer whales (>20 yr) for both females $(F$, light shading) and males ( $\mathrm{M}$, dark shading) are also depicted

2005 were predicted using the KW(age)-FA model and an age distribution for each of the 2 ecotypes created for those killer whales having predicted ages $\geq 20 \mathrm{yr}$. The population pyramids depicting the age distributions of the adult male resident and transient killer whales are shown in Fig. 7. The resident population $\left(\mathrm{n}_{\text {total }}=47\right)$ included killer whales from CAI $(\mathrm{n}=7)$, EAI $(\mathrm{n}=19)$, GOA $(\mathrm{n}=20)$ and SEA $(\mathrm{n}=1)$. The transient population $\left(\mathrm{n}_{\text {total }}=23\right)$ included whales from the Bering Sea $(n=1)$, EAI $(n=17)$, GOA $(n=1)$, Prince William Sound $(\mathrm{n}=2)$ and SEA $(\mathrm{n}=2)$. The median predicted ages of the adult male transient and resident killer whale populations from these widely overlapping regions were 22.3 and $26.9 \mathrm{yr}$, respectively. Most enlightening was the observation that the mean \pm SE age of the transient population $(24.7 \pm 1.2 \mathrm{yr})$ was significantly lower $(p<0.04)$ than the mean age of the resident population $(28.4 \pm 1.0 \mathrm{yr})$ sampled in these areas.

\section{DISCUSSION}

Although there appears to be a weak, yet significant, positive relationship between age and the percent composition of wax/sterol esters in the outer blubber of killer whales in the eastern North Pacific Ocean (particularly for females), the correlation (Fig. 2) is not sufficiently high to be quantitatively useful. At present there is no clear understanding concerning the origin of wax/sterol esters in the blubber of these cetaceans or why they appear to be somewhat elevated in females relative to males. However, it is generally accepted that deposition of waxes is not necessarily linked to dietary wax intake across all animal phyla, such that waxes can be synthesized de novo in the adipose tissue of predators. However, the observed increase in wax/sterol esters with age is generally consistent with the findings of other researchers reporting a general increase in fatty acid stratification in the blubber of numerous cetaceans and pinnipeds with age and/or body size (Koopman et al. 1996, Koopman 2007) and our previous findings wherein we demonstrated that wax/sterol esters are likewise significantly stratified in killer whale blubber (Krahn et al. 2004). Regardless of the mechanism responsible for this apparent increase in wax/sterol ester with age in killer whales, it is clear that there is a high degree of variability among individuals such that the composition of wax/sterol esters will be, at best, only a qualitative indicator of killer whale age.

In contrast to the weak correlation of wax/sterol esters with known killer whale age, many individual FAs present in the outer blubber layers exhibited a much stronger correlation with age, and unlike wax/ sterol esters, appeared to be correlated with age for both males and females (Fig. 3). It is informative to note that the classes of FAs that are most correlated with age are those that are widely believed to be endogenous rather than exogenous (dietary) in origin (Iverson et al. 2004). These include, but are not limited to, the short-chain monounsaturated (SCMU), branched-chain, and odd-chain FAs that are primarily synthesized in the liver or by bacteria in the gut (Annous et al. 1997, Nichols et al. 2002). Although the 


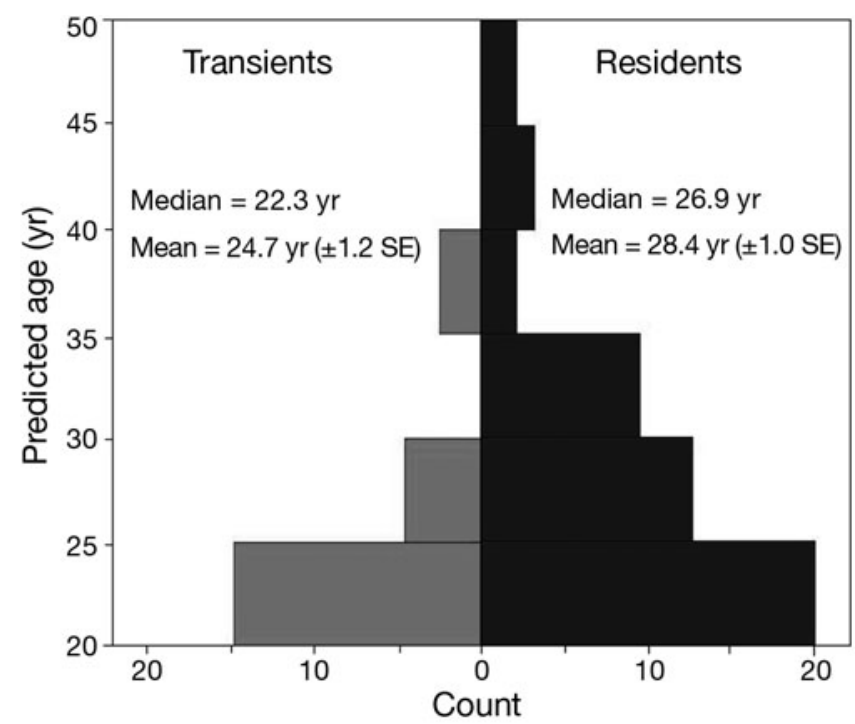

Fig. 7. Orcinus orca. Comparison of the age distribution structure of adult male resident $(n=47)$ and adult male transient ( = 23) killer whale populations inhabiting Alaskan coastal waters (including the Bering Sea). Ages of the individual transient and resident killer whales represented by these distributions were predicted using the killer whale (age)-fatty acid model (Eq. 1) from their measured outer blubber fatty acid compositions. Median and mean ages $( \pm \mathrm{SE})$ for each of these 2 ecotype populations are also imbedded within the figure

SCMU FAs are among the most highly stratified among all the FAs found in the blubber of many marine mammals, including killer whales (Koopman et al. 1996, Hooker et al. 2001, Krahn et al. 2004), we previously found very low, almost negligible, degrees of stratification for the branched- and odd-chain FAs present in the blubber of killer whales. Consequently, whereas much of the observed increase in SCMU FAs with killer whale age may be directly attributable to an increase in FA stratification with age for SCMU-type FAs, this phenomenon cannot explain why many of the branched-chain FAs also correlate well with age (Table 1, Fig. 3).

Of greater significance to this discussion of the relationship between blubber FAs and killer whale age is the observation that most individual FAs change differently with age when these whales are grouped by ecotype. This difference between resident and transient killer whales is most pronounced for the shortchain monounsaturated FAs (Fig. 3). In particular, with the sole exception of $\mathrm{C} 16: 1 \mathrm{n} 11$, the wt\% compositions of all the desaturation products of myristic (C14:0) and palmitic acid (C16:0) were consistently elevated in the transient population relative to residents when comparing individuals of comparable age. Many of these observed differences were probably attributable to the very different presumptive diets of whales in these 2 ecotypes, specifically, diets composed primarily of fish for residents and marine mammals for transients, respectively. In a previous study (Herman et al. 2005) we noted that most short-chain monounsaturated FAs are consistently higher in the blubber of marine mammals (both pinnipeds and cetaceans) than in whole bodies of nearly all species of marine fish. Thus, it appears that diet is continuing to exert a small yet discernable influence on the outer blubber composition of these predators and explains, at least in part, the elevated levels of short-chain FAs observed in the mammal-eating transients relative to the residents of similar age. These differences between the 2 ecotypes in their respective relationships between killer whale age and individual blubber FAs appear to be true, not only for short-chain monounsaturated FAs, but also are observed at various levels for each of the 64 quantifiable FAs measured in this study (Table 1). Therefore, it is not possible to use a single equation model to accurately predict the ages of both fish-eating resident and mammal-eating transient whales from the composition of any one individual FA.

In contrast, it appears that specific ratios of endogenous fatty acids present in the outer blubber of resident and transient killer whales were largely independent of their obvious long-term dietary differences and these ratios increased linearly with killer whale age (Fig. 4). Although the anteiso-C15:0/C15:0 ratio was the dominant factor in the optimum KW(age)FA model (Eq. 1), addition of the second FA ratio (C16:1n9/iso-C16:0) significantly reduced the amount of scatter of individual data points about the regression equation line and was, therefore, retained in the final, optimum multi-linear model equation. The most remarkable feature of this model is that it appears not only to be independent of diet (as evidenced by the fact that data for the fish-eating residents and the mammal-eating transients fall along the same regression line), but it is also surprisingly independent of the gender and foraging locations of these whales (Table A1). Moreover, because whales feeding on lowfat diets, or feeding less frequently, will likely experience vastly different patterns of lipid mobilization and deposition than their well-fed counterparts, and because the individual known-age whales studied herein probably represent individuals of differing nutritional status, it appears that the specific FA ratios appearing in Eq. (1) are for the most part largely unaffected by nutritional status. The efficacy of this model to killer whales outside the area of this specific study (i.e. the eastern North Pacific Ocean) is presently unknown. Moreover, we have no means at present by which to assess the ability of this model to accurately predict the ages of offshore-type killer whales due to the fact that none of the ENP offshore-type killer whale biopsy samples acquired and analyzed for FA in any of these 
studies (Herman et al. 2005, Krahn et al. 2007a) were of known age. Hence, ages predicted by this model for offshore-type whales will not be reported until the validity of this model can be adequately substantiated for this ecotype.

Among all the eastern North Pacific killer whale populations biopsied, only the GOA resident and EAI resident and transient populations were collected in sufficient number to enable age distribution histograms of any statistical significance to be generated from their blubber fatty acid compositions (Eq. 1). This is particularly true if we consider that only adult male (>20 yr) sub-populations are believed to have been randomly sampled during the course of this study, and similar to what is known about the age distribution of the well-characterized southern resident killer whale population (Ford et al. 2000, Plater 2001, J. K. B. Ford, G. M. Ellis and K. C. Balcomb unpubl. data), adult males could perhaps account for as little as 10 to $15 \%$ of their respective total populations. Juvenile killer whales represented smaller, less attainable targets during sampling efforts, and by consequence, are largely under-represented as an age class among the greater population. Moreover, biopsy sampling of females of reproductive age (i.e. $\sim 13+$ yr) is believed to be pseudo-random (marginally non-random) due to a preference to not disturb calve-rearing females during sampling operations. Hence, all comparisons between the age distributions for the various ENP killer whale populations sampled as part of this study were necessarily limited to those in which the number of adult males is adequate to produce a meaningful age structure pyramid.

Although the age distributions of the EAI and GOA adult age resident killer whale populations derived from blubber fatty acid composition were somewhat dissimilar and were derived from relatively small numbers of individuals, both populations were observed to exhibit the same pseudo-exponential decrease in population number per decade as is generally observed for the known-age west coast southern resident population (Fig. 6). Population pyramids exhibiting this same exponential (expansive) age structure generally connote populations in which birth rates are generally comparable with adult mortality rates. However, we will not know for certain if the EAI and GOA resident populations indeed mimic the classical pyramidal age structure observed for the entire southern resident population (i.e. all ages) unless sampling operations designed to guarantee random biopsy sampling of the pre-adult age killer whales (i.e. less than approximately 20 or 13 yr for males and females, respectively) are conducted in these more remote geographical locations.

The median ages of adult male southern resident and EAI resident (EAI/R) killer whales were similar, suggesting that adult age mortality rates and life expectancies may be quite similar in these 2 populations. In contrast, the median age of the adult male resident killer whales from the GOA was somewhat higher and contained a much higher proportion of males older than 30 yr. However, we should caution that in the case of the EAI residents and GOA residents(GOA/R), the numbers of adult male killer whales actually sampled ( $\mathrm{n}=19$ each) was admittedly small and represented a small percentage of the total population (at least 360 total GOA residents, Matkin et al. 1999; at least 901 EAI residents, Matkin et al. 2007). Although the numbers of adult females sampled from the EAI/R and GOA/R populations were very low, the median ages of the adult females from each of the 3 resident populations were observed to be greater than their male counterparts and were probably due to their significantly greater life expectancies (Olesiuk et al. 1990, Matkin et al. 1999, Ford et al. 2000).

One of the more interesting findings of this study was that adult male transient killer whales in Alaska appeared to have a lower median age than did their resident counterparts occupying the same general regions (Fig. 7). The most significant implication of this result is that these data provide some evidence for the first time that transient killer whales in Alaska may have lower life expectancies than sympatric resident killer whale populations foraging in the same area. This conclusion is further substantiated by the fact that a much larger number of resident killer whales attained ages $\geq 30$ yr than did their transient counterparts. For example, among the 47 adult male resident killer whales depicted in Fig. 7, approximately $28 \%$ (13 of 47 total) exceeded $30 \mathrm{yr}$ of age whereas the number of transients exceeding this age was approximately $13 \%$ ( 3 of 23 total). Although mean life expectancy values cannot be determined from a single age distribution plot such as the 2 shown for adult male residents and transients in Fig. 7, these data do provide some initial evidence that transient killer whales may have shorter life spans than residents. Unfortunately, too few female killer whales having predicted ages $\geq 20 \mathrm{yr}$ have been collected and analyzed for FAs to assess whether this difference in life expectancy between these 2 ecotypes is also valid for females.

Although the exact cause of the aforementioned apparent difference in life expectancy between adult male resident and adult male transient killer whales across Alaska is not known, several speculative, yet plausible, explanations can be offered. First, one possibility could be related to differences in prey availability for residents and transients in the Gulf of Alaska and western Alaska, where most of the samples were obtained. Resident killer whales have been increasing in the Gulf of Alaska (Matkin et al. 2003) and possibly 
in the eastern Aleutian Islands (Matkin et al. 2007). In the Gulf of Alaska increasing stocks of Pacific salmon Oncorhynchus spp., a primary prey (Saulitis et al. 2000), may have provided nutritionally favourable conditions. Conversely, some prey species of transient killer whales (e.g. harbor seals Phoca vitulina, Steller sea lions Eumetopias jubatas and northern fur seals Callorhinus ursinus) have declined in recent decades in western Alaska (York 1987, Pitcher 1990, Trites 1992, Loughlin \& York 2000, Springer et al. 2003), and conditions for transients may be degraded although trajectories of transient populations have not been determined. However, we should caution that at present no direct evidence for this hypothesis (i.e. greater prey shortages for the transient ecotype) has been reported as the trajectory of other prey species (e.g. minke whales Balaenoptera acutorostrata or Dall's porpoise Phocoenoides dalli) is not known. Second, several of the marine mammal prey of transient killer whales are formidable opponents that could potentially inflict severe, perhaps life-shortening, wounds to these whales during predation events. For example, a gray whale Eschrichtius robustus has been documented killing a walrus Odobenus rosmarus (Mazzone 1987), and Eschricht (1866) reported a second-hand account of a killer whale killed by a bowhead whale Balaena mysticetus during an attack on the latter. Finally, transient killer whales in Alaska generally feed at much higher trophic levels than do residents (Herman et al. 2005, Krahn et al. 2007a) and, therefore, accumulate persistent organic pollutants in their tissues at much higher levels ( 10 to $20 \times)$. At these much higher levels, transient killer whales may become immune-suppressed and more susceptible to infectious disease (Hall et al. 1992, DeSwart et al. 1994, Jepson et al. 1999, Loge et al. 2005) or may develop other physiological disorders (e.g. skeletal deformities, endocrine disruption; Brouwer et al. 1989, Zakharov \& Yablokov 1990) leading to premature mortalities.

Although we fully acknowledge that the current KW(age)-FA model (Eq. 1) is entirely empirical in nature, it appears to be adequately robust to enable the ages of killer whales to be predicted with sufficient precision $(\sigma= \pm 3.8 \mathrm{yr})$ to generate decadal age distribution data. Unfortunately, we presently lack a clear understanding of the underlying biological phenomena responsible for the age-FA correlation. In the future, experiments will be conducted to gain an understanding of the origins of the KW(age)-FA relationship in order to give the model a more mechanistic underpinning as well as potentially improve the accuracy and precision of the age prediction estimates. To accomplish this, experiments will be conducted to determine what compartment within a skin-blubber biopsy sample contains individual fatty acids (or FA ratios) that exhibit the best correlation with known killer whale age (e.g. skin lipids, the first few millimetres of outermost blubber adjoining the skin or inner blubber). In addition, the lipids extracted from each of these compartments will be separated by lipid class, and the FA composition of each of the 5 lipid classes will be measured separately and correlated with known killer whale age. Similar to results observed by Nazzaro-Porro et al. (1979) in human surface skin lipids, we anticipate that the FAs associated with a single isolated lipid class in 1 of these 3 compartments will correlate better with age leading to a greatly improved, more precise KW(age)-FA model that would be applicable to not only eastern North Pacific killer whales, but perhaps also to killer whale populations worldwide. Finally, it is our intention to explore the possibility that this novel approach of using endogenous blubber FAs to estimate the ages of free-ranging killer whales can be expanded to many other species of cetaceans (and if successful, perhaps also pinnipeds) and used effectively to provide better age data for a wide range of marine mammals.

Acknowledgements. We greatly appreciate the technical assistance of D. W. Brown, C. A. Sloan and J. L. Bolton in sample and data analysis. Thanks also are given to W. L. Reichert and D. P. Noren for their careful reviews of this manuscript. We are grateful for the funding support of the North Pacific Research Board (NPRB Project Nos. 0411 \& 0535) and T. K. Rowles from the Marine Mammal Health and Stranding Response Program of NOAA Fisheries. The following additional funding sources in support of field operations are also gratefully acknowledged: The National Marine Mammal Laboratory for sampling operations in southeast Alaska, GOA and Bering Sea; The Cooperative Institute for Arctic Research, The Steller Sea Lion Research Initiative; The Alaska SeaLife Center; The North Pacific Universities Marine Mammal Research Consortiums, Cascadia Research Collective, who assisted NWFSC staff with collections of southern resident killer whales in Washington. The participation of D. Matkin in sampling the west coast transient whales from Islas Bay and Icy Straight is also acknowledged. Finally, we thank L. Jones of the NWFSC Marine Mammal Program for both programmatic and financial support. Killer whale biopsy samples were collected under one of the following permits: NGOS NOAA Permit No. 545-1488-03; MMPA Permit Nos. 782-1510 and 782-1719; NMFS Permit Nos. 932-1489-05, 473-1700-01 and 7774-1714-03; and NMFS ESA/MMPA Permit No. 781-1824.

\section{LITERATURE CITED}

Akcakaya HR (2000) Population viability analyses with demographically and spatially structured models. Ecol Bull 48: $23-38$

Annous BA, Becker LA, Bayles DO, Labeda DP, Wilkinson BJ (1997) Critical role of anteiso-C15:0 fatty acid in the growth of Listeria monocytogenes at low temperatures. Appl Environ Microbiol 63:3887-3894

Barrett-Lennard LG (2000) Population structure and mating patterns of killer whales (Orcinus orca) as revealed by 
DNA analysis. PhD thesis, University of British Columbia, Vancouver

Barrett-Lennard LG, Smith TG, Ellis GM (1996) A cetacean biopsy system using lightweight pneumatic darts, and its effect on the behavior of killer whales. Mar Mamm Sci 12:14-27

Bigg MA, Olesiuk SM, Ellis GM, Ford JKB, Balcomb KC (1990) Social organization and genealogy of resident killer whales (Orcinus orca) in the coastal waters of British Columbia and Washington State. Rep Int Whal Comm Spec Issue 12:383-405

Brault S, Caswell H (1993) Pod-specific demography of killer whales (Orcinus orca). Ecology 74:1444-1454

$>$ Brouwer A, Reijnders PJH, Koeman JH (1989) Polychlorinated biphenyl (PCB)-contaminated fish induces vitamin $\mathrm{A}$ and thyroid hormone deficiency in the common seal (Phoca vitulina). Aquat Toxicol 15:99-106

Caswell H (2001) Matrix population models: construction, analysis, and interpretation. Sinauer, Sunderland, MA

> Caughley G (1966) Mortality patterns in mammals. Ecology 47:906-918

Dahlheim ME, Ellifrit DK, Swenson JD (1997) Killer whales of southeast Alaska - a catalogue of photo-identified individuals. National Marine Mammal Laboratory, Seattle, WA

DeSwart RL, Ross PS, Vedder LJ, Timmerman HH and others (1994) Impairment of immune function in harbour seals (Phoca vitulina) feeding on fish from polluted waters. Ambio 23:155-159

Durban JW, Parsons KM (2006) Laser-metrics of free-ranging killer whales. Mar Mamm Sci 22:735-743

Eschricht DF (1866) On the species of the genus Orca inhabiting the northern seas. In: Flower WH (ed) Recent memoirs on the Cetacea. Royal Society of London, London, p 151-188

Ford JKB, Ellis GM (1999) Transients - mammal-hunting killer whales of British Columbia and Washington, and Southeastern Alaska. University of British Columbia Press, Vancouver

Ford JKB, Ellis GM, Balcomb KC (2000) Killer whales - the natural history and genealogy of Orcinus orca in British Columbia and Washington, 2nd edn. University of British Columbia Press, Vancouver

Hall AJ, Law RJ, Wells DE, Harwood J and others (1992) Organochlorine levels in common seals (Phoca vitulina) which were victims and survivors of the 1988 phocine distemper epizootic. Sci Total Environ 115:145-162

> Herman DP, Burrows DG, Wade PR, Durban JW and others (2005) Feeding ecology of eastern North Pacific killer whales from fatty acid, stable isotope, and organochlorine analyses of blubber biopsies. Mar Ecol Prog Ser 302: 275-291

Hoelzel AR, Dahlheim ME, Stern SJ (1998) Low genetic variation among killer whales (Orcinus orca) in the eastern North Pacific and genetic differentiation between foraging specialists. J Hered 89:121-128

> Hoelzel AR, Natoli A, Dahlheim ME, Olavarria C, Baird RW, Black NA (2002) Low worldwide genetic diversity in the killer whale (Orcinus orca); implication for demographic history. Proc R Soc Lond B Biol Sci 269:1467-1473

Hooker SK, Iverson SJ, Ostrom P, Smith SC (2001) Diet of northern bottlenose whales inferred from fatty acid and stable-isotope analyses of biopsy samples. Can J Zool 79:1442-1454

Iverson SJ, Field C, Bowen WD, Blanchard W (2004) Quantitative fatty acid signature analysis: a new method of estimating predator diets. Ecol Monogr 74:211-235

> Jepson PD, Bennett PM, Allchin CR, Law RJ and others (1999) Investigating potential associations between chronic exposure to polychlorinated biphenyls and infectious disease mortality in harbour porpoises from England and Wales. Sci Total Environ 243-244:339-348

Kasuya T, Marsh H (1984) Life history and reproductive biology of the short-finned pilot whale, Globicephala macrorhyncus, off the Pacific coast of Japan. Rep Int Whaling Comm Spec Issue 6:259-310

Koopman HN (2007) Phylogenetic, ecological, and ontogenic factors influencing the biochemical structure of the blubber of odontocetes. Mar Biol 151:277-291

> Koopman HN, Iverson SJ, Gaskin DE (1996) Stratification and age-related differences in blubber fatty acids of the male harbour porpoise (Phocoena phocoena). J Comp Physiol B 165:628-639

Koopman HN, Iverson SJ, Read AJ (2003) High concentrations of isovaleric acid in the fats of odontocetes: variation and patterns of accumulation in blubber vs. stability in the melon. J Comp Physiol B 173:247-261

Krahn MM, Herman DP, Ylitalo GM, Sloan CA and others (2004) Stratification of lipids, fatty acids and organochlorine contaminants in blubber of white whales and killer whales. J Cetacean Res Manag 6:175-189

Krahn MM, Herman DP, Matkin CO, Durban JW and others (2007a) Use of chemical tracers in assessing the diet and foraging regions of eastern North Pacific killer whales. Mar Environ Res 63:91-114

Krahn MM, Hanson MB, Baird RW, Boyer RH and others (2007b) Persistent organic pollutants and stable isotopes in biopsy samples (2004/2006) from southern resident killer whales. Mar Pollut Bull 54:1903-1911

Lockyer C, Heide-Jørgensen MP, Jensen J, Kinze CC, BuusSørensen T (2001) Age, length and reproductive parameters of harbour porpoises Phocoena phocoena (L.) from West Greenland. ICES J Mar Sci 58:154-162

Loge FJ, Arkoosh MR, Ginn TR, Johnson LL, Collier TK (2005) Impact of environmental stressors on the dynamics of disease transmission. Environ Sci Technol 39:7329-7336

Loughlin TR, York AE (2000) An accounting of the sources of Steller sea lion mortality. Mar Fish Rev 62:40-45

Matkin C, Ellis G, Saulitis E, Barrett-Lennard L, Matkin D (1999) Killer whales of Southern Alaska. North Gulf Oceanic Society, Homer, AK

Matkin CO, Ellis GM, Barrett-Lennard LG, Yurk H and others (2003) Photographic and acoustic monitoring of killer whales in Prince William Sound and Kenai Fjords. Exxon Valdez Oil Spill Restoration Project Final Report (Restor Proj 03012 Final Rep), North Gulf Oceanic Society, Homer, AK

Matkin CO, Barrett-Lennard LG, Yurk H, Ellifrit D, Trites AW (2007) Ecotypic variation and predatory behavior among killer whales (Orcinus orca) off the Eastern Aleutian Islands, Alaska. Fish Bull 105:74-87

Mazzone WS (1987) Walrus, Odobenus rosmarus, and whale interactions: an eyewitness account. Can Field-Nat 101:590-591

Nazzaro-Porro M, Passi S, Boniforti L, Belsito F (1979) Effects of aging on fatty acids in skin surface lipids. J Invest Dermatol 73:112-117

Nichols DS, Presser KA, Olley J, Ross T, McMeekin TA (2002) Variation of branched-chain fatty acids marks the normal physiological range for growth in Listeria monocytogenes. Appl Environ Microbiol 68:2809-2813

Olesiuk PF, Bigg MA, Ellis GM (1990) Life history and population dynamics of resident killer whales (Orcinus orca) in the coastal waters of British Columbia and Washington State. Rep Int Whal Comm Spec Issue 12:209-243

Olesiuk PF, Ellis GM, Ford JKB (2005) Life history and popu- 
lation dynamics of northern resident killer whales (Orcinus orca) in British Columbia. Canadian Science Advisory Secretariat Res Doc 2005/045. Fisheries and Oceans, Nanaimo

Pitcher KW (1990) Major decline in number of harbor seals (Phoca vitulina richardsi) on Tugidak Island, Gulf of Alaska. Mar Mamm Sci 6:121-134

Plater B (2001) Petition to list the southern resident killer whale (Orcinus orca) as an endangered species under the endangered species act, 1 May 2001. Appendix A. Center for Biologic Diversity, Berkeley, CA, p 87-88

Read AJ, Hohn AA (1995) Life in the fast lane: the life history of harbor porpoises from the Gulf of Maine. Mar Mamm Sci 11:423-440

Read AJ, Wells RS, Hohn AA, Scott MD (1993) Patterns of growth in wild bottlenose dolphins, Tursiops truncatus. J Zool 231:107-123

Ross PS, Ellis GM, Ikonomou MG, Barrett-Lennard LG, Addison RF (2000) High PCB concentrations in free-ranging Pacific killer whales, Orcinus orca: effects of age, sex and dietary preference. Mar Pollut Bull 40:504-515

Saulitis EL, Matkin CO, Barrett-Lennard L, Heise K, Ellis GM (2000) Foraging strategies of sympatric killer whale (Orcinus orca) populations in Prince William Sound, Alaska. Mar Mamm Sci 16:94-109

Sloan CA, Brown DW, Ylitalo GM, Buzitis J and others (2006) Quality assurance plan for analyses of environmental samples for polycyclic aromatic compounds, persistent organic pollutants, fatty acids, stable isotope ratios, lipid classes, and metabolites of polycyclic aromatic compounds. US

Editorial responsibility: Hans Heinrich Janssen, Oldendorf/Luhe, Germany
Dept Commerce NOAA Tech Memo NMFS-NWFSC-77

Springer AM, Estes JA, van Vliet GB, Williams TM and others (2003) Sequential megafaunal collapse in the North Pacific Ocean: an ongoing legacy of industrial whaling? Proc Natl Acad Sci USA 100:12223-12228

Stolen MK, Barlow J (2003) A model life table for bottlenose dolphins (Tursiops truncatus) from the Indian River Lagoon system, Florida, USA. Mar Mamm Sci 19:630-649

Trites AW (1992) Northern fur seals: Why have they declined? Aquat Mamm 18:3-18

> Ylitalo GM, Matkin CO, Buzitis J, Krahn MM, Jones LL, Rowles T, Stein JE (2001) Influence of life-history parameters on organochlorine concentrations in free-ranging killer whales (Orcinus orca) from Prince William Sound, AK. Sci Total Environ 281:183-203

Ylitalo GM, Yanagida GK, Hufnagle L, Krahn MM (2005) Determination of lipid classes and lipid content in tissues of aquatic organisms using a thin layer chromatography/flame ionization detection (TLC/FID) microlipid method. In: Ostrander GK (ed) Techniques in aquatic toxicology, Vol 2. CRC Press, Boca Raton, FL, p 227-237

York AE (1987) Northern fur seal (Callorhinus ursinus) eastern Pacific population (Pribilof Islands, Alaska, and San Miguel Island, California). In: Croxall JP, Gentry RL (eds) Status, biology, and ecology of fur seals. NOAA Tech Rep NMFS-51, US Dept Commerce, Washington, DC, p 9-21

Zakharov VM, Yablokov AV (1990) Skull asymmetry in the Baltic grey seal: effects of environmental pollution. Ambio 19:266-269

Submitted: November 27, 2007; Accepted: August 25, 2008

Proofs received from author(s): November 26, 2008 